\title{
Oceanography
}

CITATION

Greene, C.H. 2016. Wading in the footsteps of an ecological giant.

Oceanography 29(2):5-6, http://dx.doi.org/10.5670/oceanog.2016.25.

DOI

http://dx.doi.org/10.5670/oceanog.2016.25

COPYRIGHT

This article has been published in Oceanography, Volume 29, Number 2, a quarterly journal of The Oceanography Society. Copyright 2016 by The Oceanography Society. All rights reserved.

USAGE

Permission is granted to copy this article for use in teaching and research. Republication, systematic reproduction, or collective redistribution of any portion of this article by photocopy machine, reposting, or other means is permitted only with the approval of The Oceanography Society. Send all correspondence to: info@tos.org or The Oceanography Society, PO Box 1931, Rockville, MD 20849-1931, USA. 


\section{Wading in the Footsteps of an Ecological Giant}

The great American marine ecologist Robert T. (Bob) Paine passed away in Seattle on June 13, 2016. During the last half century, Bob introduced some of the most important conceptual advances in community ecology, perhaps none more influential than that of the keystone species. A keystone species is one that has a disproportionately large effect on its surrounding community. Such a species plays a critical role in maintaining the community's structure, affecting many other organisms, and helping to determine the types and numbers of various other species found in that community.

The keystone species concept came to Bob as he pondered the spectacular wave-swept shores of the Pacific Northwest's rocky intertidal. Arriving at the University of Washington in 1962 as a new assistant professor, Bob applied the concepts that he had learned at the University of Michigan from three of the most influential ecologists of their day-Nelson Hairston, Fred Smith, and Larry Slobodkin. In 1960, this trio published one of the all-time classic papers in ecology-"Community Structure, Population Control, and Competition." This paper, which is referred to by most ecologists today simply as "HSS," laid the foundation for a career Bob spent experimentally tinkering in the ecology between Pacific tides.

HSS hypothesized that the world was green because the populations of herbivorous species grazing on green plants were held in check by predatory species higher up the food chain. This revolutionary idea tipped the world of community ecology upside down. Prior to HSS, most ecologists viewed natural communities as being structured from the bottom up, with the amount of energy flowing from lower to higher trophic levels in the food chain determining community structure. Bob took this top-down worldview from the land-locked campus of the University of Michigan and applied it to the familiar but poorly understood rocky shores of Washington state.

Fifty years ago this year, Bob published his own classic paper, "Food Web Complexity and Species Diversity," which sketched out ideas that would later become known as the keystone species and trophic cascade concepts. Bob had found that by experimentally removing the predatory ochre sea star, Pisaster ochraceus, from the seashore, he could fundamentally alter the intertidal community's structure and diversity. The effects of Pisaster's removal cascaded down the food chain, eliminating certain species and altering the web of interactions occurring among the rocky shore's other inhabitants. To future generations of ecologists being trained around the world, Pisaster became known as the quintessential keystone predator. This concept was subsequently extended to include other species whose removal or addition disproportionately affected the communities around them.

Similar to the keystone species he studied, Bob's intellectual contributions had a disproportionate effect on the field of community ecology. Not only did he develop important theoretical concepts, he also demonstrated the value of field experiments in testing ecological theory. By example, Bob became the progenitor of a vast school of experimental ecologists (Figure 1), most working in marine environments, but some also venturing into terrestrial and freshwater realms. Bob's influence spread well beyond the direct descendants on his academic family tree. In fact, many attribute Bob's promotion of the field experimental approach as one of the great turning points in twentieth century ecology.

As fundamental as Bob's contributions have already been to basic ecological theory, their application to practical, realworld problems will play an increasingly important role as society attempts to understand and grapple with the problems arising in our rapidly changing ocean. For example, during the persistent ocean heat wave that has plagued coastal waters from California to Alaska during the past three years (see article by Cavole et al., 2016, in this issue, for further discussion), there has been a collapse of most sea star populations in rocky intertidal and shallow subtidal habitats. Sea star wasting syndrome appears to be responsible for a majority of these temperature-mediated disease outbreaks (Pfister et al., 2016). Laying waste to not only Pisaster in the intertidal, but also to the subtidal keystone predator, the sunflower star Pycnopodia 


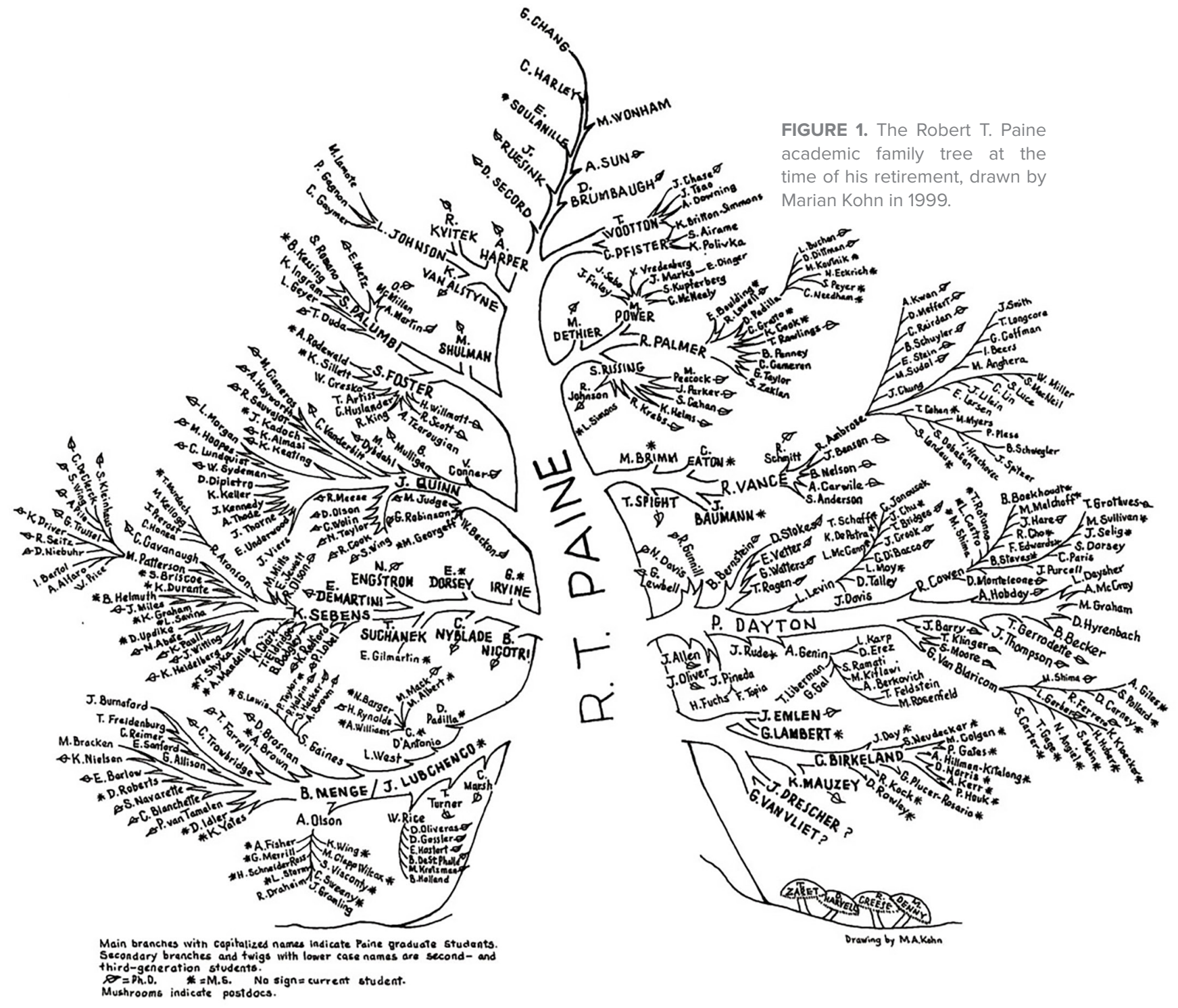

helianthoides, sea star wasting disease is altering rocky seashore communities on an unprecedented scale.

In many subtidal habitats in Northern California, purple urchin populations have increased in abundance by nearly an order of magnitude. Combined with warmer ocean temperatures unfavorable to kelp growth, sea urchin grazing has reduced many of the West Coast's lush and diverse kelp forests to barren grounds of grazer-resistant coralline algae. Devoid of the kelp providing protection and nutrition, these urchin barren grounds can no longer sustain the high diversity and productivity of invertebrate and fish species characteristic of kelp forest communities.

Was the disappearance of Pycnopodia responsible for the coincident population explosion of purple urchins? The contributions of Bob and his students and colleagues have provided us with the theoretical framework and experimental methods required to tease out the ecological basis for the observed ecosystem regime shift. If the release of urchins from sea star predation has played a significant role in triggering this regime shift, then it is unlikely the kelp forests will recover to their former

state, even with the return of cooler La Niña conditions, without some sort of natural perturbation or human intervention to reduce urchin abundance. I can picture the smile on Bob's face as his academic offspring contemplate how to make the world of kelp forests green again.

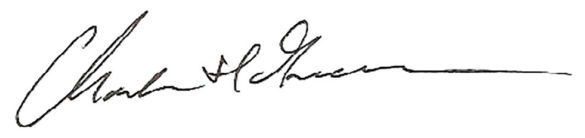

Charles H. Greene, Associate Editor, Oceanography

\section{REFERENCES}

Cavole, L.M., A.M. Demko, R.E. Diner, A. Giddings, I. Koester, C.M.L.S. Pagniello, M.-L. Paulsen, A. Ramirez-Valdez, S.M. Schwenck, N.K. Yen, and others. 2016. Biological impacts of the 2013-2015 warm-water anomaly in the Northeast Pacific: Winners, losers, and the future. Oceanography 29(2):273-285, http://dx.doi.org/10.5670/oceanog.2016.32.

Hairston, N.G., F.E. Smith, and L.B. Slobodkin. 1960. Community structure, population control, and competition. The American Naturalist 94(879):421-425.

Paine, R.T. 1966. Food web complexity and species diversity. The American Naturalist 100(910):65-75.

Pfister, C.A., R.T. Paine, and J.T. Wooten. 2016. The iconic keystone predator has a pathogen. Frontiers in Ecology and the Environment 14(5):285-286, http://dx.doi.org/10.1002/fee.1292. 